\title{
Constraints on superoxide mediated formation of manganese oxides
}

\author{
Deric R. Learman' ${ }^{1}$,Bettina M. Voelker ${ }^{2}$, Andrew S. Madden ${ }^{3}$ and Colleen M. Hansel ${ }^{4}$ * \\ 1 Institute for Great Lakes Research and Department of Earth and Atmospheric Sciences, Central Michigan University, Mount Pleasant, MI, USA \\ ${ }^{2}$ Department of Chemistry and Geochemistry, Colorado School of Mines, Golden, CO, USA \\ ${ }^{3}$ School of Geology and Geophysics, University of Oklahoma, Norman, OK, USA \\ ${ }^{4}$ Marine Chemistry and Geochemistry Department, Woods Hole Oceanographic Institution, Woods Hole, MA, USA
}

Edited by:

Stephen Wiley Ragsdale, University of Michigan, USA

\section{Reviewed by:}

Jim K. Fredrickson, Pacific Northwest National Laboratory, USA

David Emerson, Bigelow Laboratory

for Ocean Sciences, USA

\section{*Correspondence:}

Colleen M. Hansel, Marine Chemistry and Geochemistry Department, Woods Hole Oceanographic Institution, 266 Woods Hole Road, MS52, Woods Hole, MA 02543, USA e-mail:chansel@whoi.edu
Manganese $(\mathrm{Mn})$ oxides are among the most reactive sorbents and oxidants within the environment, where they play a central role in the cycling of nutrients, metals, and carbon. Recent discoveries have identified superoxide $\left(\mathrm{O}_{2}^{-}\right)$both of biogenic and abiogenic origin as an effective oxidant of $\mathrm{Mn}$ (II) leading to the formation of Mn oxides. Here we examined the conditions under which abiotically produced superoxide led to oxidative precipitation of $\mathrm{Mn}$ and the solid-phases produced. Oxidized $\mathrm{Mn}$, as both aqueous $\mathrm{Mn}(\mathrm{III})$ and $\mathrm{Mn}(\mathrm{III} / \mathrm{IV})$ oxides, was only observed in the presence of active catalase, indicating that hydrogen peroxide $\left(\mathrm{H}_{2} \mathrm{O}_{2}\right)$, a product of the reaction of $\mathrm{O}_{2}^{-}$with $\mathrm{Mn}(\mathrm{II})$, inhibits the oxidation process presumably through the reduction of $\mathrm{Mn}(\mathrm{III})$. Citrate and pyrophosphate increased the yield of oxidized $\mathrm{Mn}$ but decreased the amount of $\mathrm{Mn}$ oxide produced via formation of $\mathrm{Mn}(\mathrm{III})$ ligand complexes. While complexing ligands played a role in stabilizing $\mathrm{Mn}(\mathrm{III})$, they did not eliminate the inhibition of net $\mathrm{Mn}(\mathrm{III})$ formation by $\mathrm{H}_{2} \mathrm{O}_{2}$. The $\mathrm{Mn}$ oxides precipitated were highly disordered colloidal hexagonal birnessite, similar to those produced by biotically generated superoxide. Yet, in contrast to the large particulate Mn oxides formed by biogenic superoxide, abiotic $\mathrm{Mn}$ oxides did not ripen to larger, more crystalline phases. This suggests that the deposition of crystalline Mn oxides within the environment requires a biological, or at least organic, influence. This work provides the first direct evidence that, under conditions relevant to natural waters, oxidation of $\mathrm{Mn}(\mathrm{II})$ by superoxide can occur and lead to formation of $\mathrm{Mn}$ oxides. For organisms that oxidize $\mathrm{Mn}$ (II) by producing superoxide, these findings may also point to other microbially mediated processes, in particular enzymatic hydrogen peroxide degradation and/or production of organic ligand metabolites, that allow for $\mathrm{Mn}$ oxide formation.

Keywords: manganese oxidation, manganese oxides, superoxide, reactive oxygen species, $\mathrm{Mn}$ (III) complexes, organic ligands

\section{INTRODUCTION}

Manganese $(\mathrm{Mn})$ oxides are among the most reactive sorbents and oxidants within the environment, where they play a central role in the cycling of nutrients, metals, and carbon (Jenne, 1968; Sunda and Kieber, 1994). Despite the overall thermodynamic favorability of $\mathrm{Mn}(\mathrm{II})$ oxidation to $\mathrm{Mn}(\mathrm{IV})$ oxides by molecular oxygen $\left(\mathrm{O}_{2}\right)$, the first electron transfer step forming $\mathrm{Mn}(\mathrm{III})$ poses an aboitic reactivity barrier to this reaction and is subsequently the rate controlling step (Luther III, 2010). Consequently, homogeneous oxidation of aqueous $\mathrm{Mn}$ (II) by $\mathrm{O}_{2}$ is considered negligible in environments with a $\mathrm{pH}$ below 9 (Morgan, 2005; Luther III, 2010). The adsorption of Mn(II) to mineral surfaces (Junta and Hochella, 1994; Madden and Hochella Jr., 2005) or complexation to high-affinity ligands (Duckworth and Sposito, 2005), however, allows for the oxidation to Mn(III/IV) oxides. Further, $\mathrm{Mn}(\mathrm{II})$-oxidizing microorganisms belonging to both the bacterial and fungal domains of life are widespread and believed to be dominant drivers of Mn oxide formation within the environment (Miyata et al., 2004; Tebo et al., 2005; Santelli et al., 2010).
In contrast to the energetically prohibitive reaction between $\mathrm{Mn}$ (II) and molecular oxygen, the oxidation of $\mathrm{Mn}(\mathrm{II})$ by the reactive oxygen species (ROS) superoxide $\left(\mathrm{O}_{2}^{-}\right)$is thermodynamically favorable over all relevant $\mathrm{pH}$ conditions (0-13; Luther III, 2010). Indeed, the ability of $\mathrm{Mn}$ (II) to scavenge superoxide has been well documented (Archibald and Fridovich, 1982; Cabelli and Bielski, 1982, 1984; Nico et al., 2002; Barnese et al., 2008) and $\mathrm{Mn}(\mathrm{II})$ is touted as an important antioxidant in biological systems (Daly et al., 2004). In seawater and simulated freshwater, nanomolar levels of $\mathrm{Mn}$ (II) are able to scavenge superoxide, indicating a fast reaction which, at the superoxide levels previously measured in seawater (Rose et al., 2008; Hansard et al., 2010), should lead to a rapid $\mathrm{Mn}$ (II/III) cycle (Hansard et al., 2011). While Mn oxides could form as the result of such a cycle, Hansard et al. (2011) did not attempt to observe their formation at the low levels of Mn used in their experiments. However, in another study, formation of ROS, primarily superoxide, upon illumination of terrestrial organic carbon was implicated in the oxidation of $\mathrm{Mn}$ (II) to $\mathrm{Mn}$ oxide minerals (Nico et al., 2002). Thus, the reaction between $\mathrm{Mn}$ (II) and superoxide is likely important to the rates of both 
oxidation of $\mathrm{Mn}$ (II) and reduction of superoxide to hydrogen peroxide $\left(\mathrm{H}_{2} \mathrm{O}_{2}\right)$ in aqueous environments (reaction 1).

$$
\mathrm{Mn}(\mathrm{II})+\mathrm{O}_{2}^{-}+2 \mathrm{H}^{+} \rightarrow \mathrm{Mn}(\mathrm{III})+\mathrm{H}_{2} \mathrm{O}_{2}
$$

The production of superoxide, thought to be ubiquitous in natural surface waters, has historically been attributed to photochemical reactions, yet recent research has revealed that previously unrecognized biological sources contribute, in some cases substantially, to the dark production of ROS in both terrestrial and marine systems (Kustka et al., 2005; Rose et al., 2008; Hansard et al., 2010; Saragosti et al., 2010; Vermilyea et al., 2010; Rusak et al., 2011). In fact, enzymatic extracellular superoxide production by a marine bacterium (Roseobacter sp. AzwK-3b) within the widespread and numerically abundant Roseobacter clade (Buchan et al., 2005; Hansel and Francis, 2006) has recently been found responsible for this organism's ability to oxidize Mn(II) (Learman et al., 2011a). This biological superoxide-based $\mathrm{Mn}$ (II) oxidation pathway ultimately results in the precipitation of Mn oxides by way of a $\mathrm{Mn}$ (III) intermediate. Similarly, it was recently shown that $\mathrm{Mn}$ (II) oxidation by a number of common ascomycete fungi was a consequence of extracellular superoxide production during cell differentiation and reproduction (Hansel et al., 2012; Tang et al., 2013). In comparison to bacteria, fungal extracellular superoxide production has long been appreciated and shown to play important roles in fungal physiology and species interactions (Aguirre et al., 2005). However, the widespread production of extracellular superoxide by environmentally relevant heterotrophic bacteria has recently been recognized (Diaz et al., 2013). Considering superoxide's ubiquity in the environment and recognized role in (a)biological $\mathrm{Mn}$ (II) oxidation, reaction between superoxide and aqueous $\mathrm{Mn}$ (II) may be an important pathway for Mn oxide formation within the environment.

It is unclear, however, if the formation of Mn oxides can proceed via a reaction solely between $\mathrm{Mn}$ (II) and superoxide or if other conditions (and/or reactants) are required for nucleation and/or precipitation to occur. For example, upon reaction of $\mathrm{Mn}$ (II) and superoxide (reaction 1), $\mathrm{Mn}$ (III) could be reduced back to $\mathrm{Mn}$ (II) by $\mathrm{O}_{2}^{-}$(reaction 2; Hansard et al., 2011), back-react with $\mathrm{H}_{2} \mathrm{O}_{2}$, re-forming $\mathrm{Mn}$ (II) but not superoxide (Archibald and Fridovich, 1982; reaction 3), be further oxidized (reaction 4) or disproportionate to $\mathrm{Mn}(\mathrm{II})$ and $\mathrm{Mn}(\mathrm{IV})$ (reaction 5). $\mathrm{Mn}(\mathrm{IV})$ is unstable as an aqueous ion and thus rapid hydrolysis will result in spontaneous precipitation of $\mathrm{Mn}(\mathrm{IV})$ as a pure or mixed valence oxide (reaction 6). Thus, only the latter two scenarios (reactions 4 and 5 ) of those considered would result in the formation of Mn oxide solid-phase products (reaction 6).

$$
\begin{aligned}
& \mathrm{Mn}(\mathrm{III})+\mathrm{O}_{2}^{-} \rightarrow \mathrm{Mn}(\mathrm{II})+\mathrm{O}_{2} \\
& \mathrm{Mn}(\mathrm{III})+1 / 2 \mathrm{H}_{2} \mathrm{O}_{2} \rightarrow \mathrm{Mn}(\mathrm{II})+1 / 2 \mathrm{O}_{2}+\mathrm{H}^{+} \\
& \mathrm{Mn}(\mathrm{III})+1 / 4 \mathrm{O}_{2}+\mathrm{H}^{+} \rightarrow \mathrm{Mn}(\mathrm{IV})+1 / 2 \mathrm{H}_{2} \mathrm{O} \\
& 2 \mathrm{Mn}(\mathrm{III}) \rightarrow \mathrm{Mn}(\mathrm{II})+\mathrm{Mn}(\mathrm{IV}) \\
& \mathrm{Mn}(\mathrm{IV})+2 \mathrm{H}_{2} \mathrm{O} \rightarrow \mathrm{MnO}_{2(\mathrm{~s})}+4 \mathrm{H}^{+}
\end{aligned}
$$

Thus, despite observations of a link between $\mathrm{Mn}(\mathrm{II})$ and superoxide in $\mathrm{Mn}(\mathrm{II})$ oxidation, the potential for this reaction to directly generate solid-phase $\mathrm{Mn}$ (III/IV) oxides is not known. Here we address this uncertainty by conducting experiments reacting $\mathrm{Mn}$ (II) with abiotically generated superoxide under various conditions. We elucidate conditions necessary for the formation of $\mathrm{Mn}$ (III/IV) oxide minerals and also the compositional and structural properties of the ensuing Mn oxides. This work reveals a tightly coupled cycle between ROS and Mn that influences the stability of reactive intermediates and propensity for Mn oxide formation. This information will assist in identifying the geochemical environments that can support Mn oxide formation and additional microbial and potentially enzymatic processes that may be mediated by organisms oxidizing Mn(II) via superoxide.

\section{MATERIALS AND METHODS MATERIALS}

SOTS-1 [superoxide thermal source; di-(4-carboxybenzyl) hyponitrite] technical grade (Cayman Chemical) was used as a thermal source of superoxide (Ingold et al., 1997; Heller and Croot, 2010). SOTS-1 stock solutions $(10 \mathrm{mg} / \mathrm{mL})$ were made with $\mathrm{N}_{2}$-purged dimethyl sulfoxide (DMSO, Sigma). Solutions of artificial seawater (ASW, $0.3 \mathrm{M} \mathrm{NaCl}, 0.05 \mathrm{M} \mathrm{MgSO}_{4}, 0.01 \mathrm{M}$ $\mathrm{CaCl}_{2}$, and 0.01 M KCl; Tebo et al., 2007) contained $20 \mathrm{mM} 4$-(2hydroxyethyl)piperazine-1-ethanesulfonic acid (HEPES; EMD) adjusted to $\mathrm{pH}$ 7.6. Specific enzymes used to scavenge superoxide and hydrogen peroxide were superoxide dismutase (SOD, Sigma) and catalase (Sigma), respectively. In some conditions, soluble sodium citrate (Alfa Aesar), sodium pyrophosphate (J.T. Baker), humic acid (Sigma), bovine serum albumin (BSA, Sigma), or casamino acids (Sigma) were added as a supplement to the experiment.

\section{Mn(II) OXIDATION EXPERIMENTS}

Experiments contained 75\% ASW and HEPES in deionized water with $200 \mu \mathrm{M} \mathrm{MnCl}_{2}$, and $1 \mathrm{mM}$ SOTS-1. Experiments were conducted at room temperature and allowed to incubate for 18-24 h. Hydrogen peroxide was scavenged from experiments with the addition of $200 \mathrm{U}$ of catalase to $1 \mathrm{~mL}$ of reaction solution at time 0 , 3 , and $6 \mathrm{~h}$ (the decomposition of catalase on a time scale of hours in our systems necessitated making several additions). Some of the experiments were supplemented with SOD $(10$ or $50 \mu \mathrm{M})$, sodium pyrophosphate $(0.5 \mathrm{mM})$, sodium citrate $(0.5$ and $5 \mathrm{mM})$ and/or $10 \mathrm{mg} / \mathrm{L}$ humic acid. To make the particles that were analyzed spectroscopically, $1700 \mathrm{U}$ of catalase were added approximately every $3 \mathrm{~h}$ over a period of $27 \mathrm{~h}$.

\section{QUANTIFICATION}

Oxidized Mn was quantified by monitoring the spectroscopic (Cary 60 UV-Vis spectrophotometer, Varian) absorption $(620 \mathrm{~nm}$ ) of the samples with the addition of the colorimetric dye leucoberbelin blue (LBB, Sigma; Krumbein and Altmann, 1973), which reacts with both $\mathrm{Mn}(\mathrm{III})$ and $\mathrm{Mn}(\mathrm{IV})$. Standard curves were prepared using permanganate, $\mathrm{KMnO}_{4}$ (EMD). To convert moles of $\mathrm{KMnO}_{4}$ to moles of $\mathrm{Mn}(\mathrm{IV})$ oxide or $\mathrm{Mn}(\mathrm{III})$, conversion factors of 2.5 or 5 , respectively, were used, since each mole of $\mathrm{KMnO}_{4}$ can oxidize 2.5 or 5 times as much LBB as a mole of Mn(IV) oxide or Mn(III) (Johnson and Chiswell, 1993). 


\section{MINERAL ANALYSIS}

Mn oxides were harvested by either filtration $(0.2 \mu \mathrm{m})$ or centrifugation $(12,000 \times g$ for $25 \mathrm{~min})$. The collected Mn oxides were washed with distilled water and frozen at $-20^{\circ} \mathrm{C}$.

Transmission electron microscopy (TEM) was performed at the University of Oklahoma Samuel Roberts Noble Electron Microscopy Laboratory. Pelleted mineral samples were thawed, resuspended in ultrapure $(18.2 \mathrm{M} \Omega$ ) water, and sonicated. The liquid samples were loaded on lacey-carbon TEM grids (Ted Pella). TEM imaging was performed on a JEOL 2010-F TEM at $200 \mathrm{kV}$. Measurement and fast Fourier transform (FFT) analysis were performed with Digital Micrograph (Gatan, Inc.) and the DiffTools plugin (Mitchell, 2008).

Mn oxides were examined by X-ray absorption spectroscopy (XAS), in particular X-ray absorption near edge spectroscopy (XANES) for average oxidation state and extended X-ray absorption fine-structure (EXAFS) spectroscopy for structural information. Mn K-edge XAS spectra were collected on beamline 11-2 at the Stanford Synchrotron Radiation Lightsource (SSRL) using a $\operatorname{Si}(220)$ monochromator $\left(\Phi=90^{\circ}\right)$. Calibrations were made using a $\mathrm{KMnO}_{4}$ standard $(6543.34 \mathrm{eV})$. Fluorescence data were collected with a 30-element Ge solid-state detector array with soller slits and Cr filters. Spectra were collected (three to four scans per sample) at room temperature from -200 to approximately $+1000 \mathrm{eV}$ around the Mn K-edge (6539 keV). Data analysis of sample spectra was performed using the SIXPACK software program (Webb, 2005). XAS scans were averaged, background-subtracted, normalized, and deglitched if necessary. The absorption edge of the Mn K-edge XANES spectra was used to estimate the proportions of $\mathrm{Mn}(\mathrm{II}), \mathrm{Mn}(\mathrm{III})$, and $\mathrm{Mn}(\mathrm{IV})$ by conducting linear combination fitting (LCF) with the three model $\mathrm{Mn}$ compounds $\mathrm{MnCl}_{2}$, $\mathrm{MnOOH}$ (feitknechtite), and $\delta-\mathrm{MnO}_{2}$ (average oxidation state 3.9), respectively (Villalobos et al., 2003; Bargar et al., 2005; Webb et al., 2005a). The normalized absorption spectra were analyzed using a data range of 6560-6600 eV. Binding energies were fixed and negative component contributions were prohibited for LCF. The goodness of fit was established by minimization of the $R$ factor parameter (Newville, 2001). Previous investigations have defined the $1 \sigma$ error estimates to be $1.7,2.6$, and $2.9 \%$ for $\mathrm{Mn}(\mathrm{II})$, $\mathrm{Mn}(\mathrm{III})$, and $\mathrm{Mn}(\mathrm{IV})$, respectively (Bargar et al., 2005).

For EXAFS analysis, the $\chi(k)$ spectra were $k^{3}$-weighted and analyzed using a $k$ range of $3-12 \AA^{-1}$. LCF was performed using model compounds as described previously (Bargar et al., 2005) and include $\delta-\mathrm{MnO}_{2}$, hexagonal Na-birnessite, triclinic Ca-birnessite, groutite $(\alpha-\mathrm{MnOOH})$, feitknechtite $(\beta-\mathrm{MnOOH})$, manganite $(\gamma$-MnOOH$)$, hausmannite $\left(\mathrm{Mn}_{3} \mathrm{O}_{4}\right)$, synthetic todorokite $\left[(\mathrm{Na}, \mathrm{Ca}, \mathrm{K})(\mathrm{Mg}, \mathrm{Mn}) \mathrm{Mn}_{6} \mathrm{O}_{14} .5 \mathrm{H}_{2} \mathrm{O}\right]$, pyrolusite $\left(\beta-\mathrm{MnO}_{2}\right)$, synthetic $\mathrm{Mn}_{2} \mathrm{O}_{3}$, aqueous $\mathrm{Mn}$ (III) pyrophosphate, aqueous $\mathrm{MnCl}_{2}$, and aqueous $\mathrm{MnSO}_{4}$. For LCF, binding energies were not allowed to float, a negative component contribution was prohibited, and components were not summed to 1.0.

\section{RESULTS AND DISCUSSION Mn OXIDE PRECIPITATION}

Mn oxide minerals were not observed upon reaction between abiotically generated superoxide and aqueous $\mathrm{Mn}$ (II) (Figure 1). In ASW (75\%) buffered to a pH of 7.6, $200 \mu \mathrm{M}$ aqueous $\mathrm{Mn}$ (II) (as

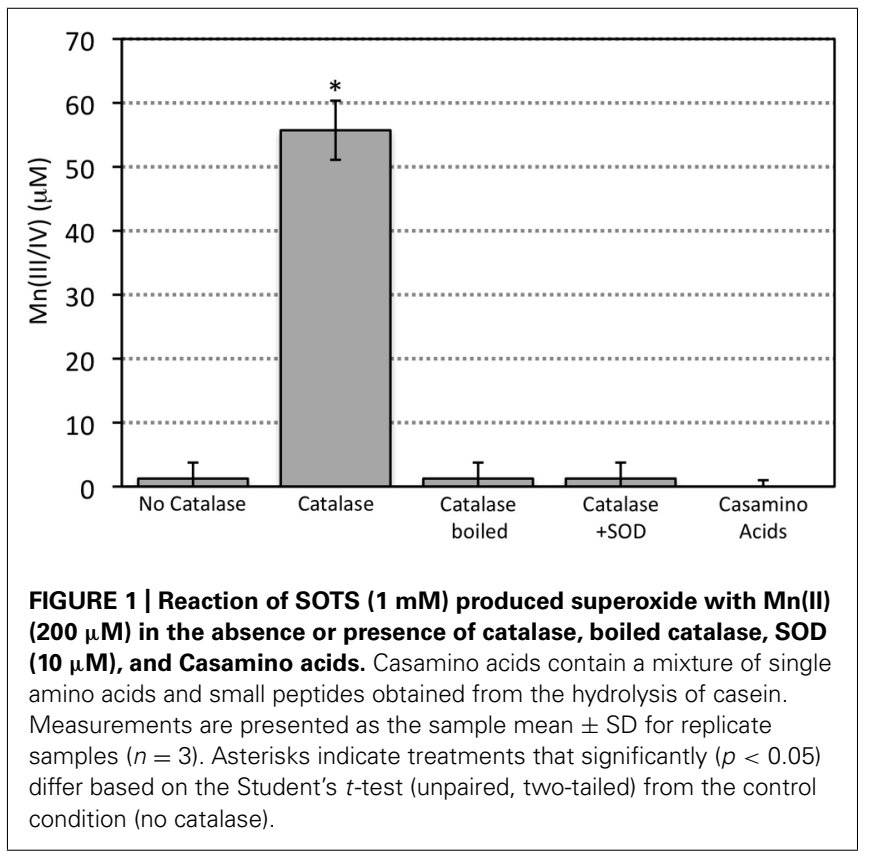

$\mathrm{MnCl}_{2}$ ) was reacted at room temperature with $1 \mathrm{mM}$ of the chemical superoxide source (SOTS-1; Ingold et al., 1997; Heller and Croot, 2010), which generates an initial superoxide flux of about $6 \mathrm{nM} \mathrm{s}^{-1}$ (Heller and Croot, 2010). Following several days of reaction, visible Mn oxide precipitates or discoloration of the ASW solution was not observed. Addition of the colorimetric dye LBB (Krumbein and Altmann, 1973), which oxidizes and turns blue in the presence of both $\mathrm{Mn}(\mathrm{III})$ and $\mathrm{Mn}(\mathrm{IV})$, showed no reaction, confirming the absence of oxidized Mn within the reacted solution (Figure 1). Since LBB reacts with both $\mathrm{Mn}(\mathrm{III})$ and $\mathrm{Mn}(\mathrm{IV})$, these results indicated that either (1) Mn(II) was not oxidized by superoxide or that (2) the intermediate product $\mathrm{Mn}$ (III) was being reduced back to $\mathrm{Mn}$ (II) (Archibald and Fridovich, 1982) before $\mathrm{Mn}$ (IV) could form and spontaneously precipitate. Considering the demonstrated ability of superoxide to oxidize $\mathrm{Mn}$ (II) at these and lower superoxide fluxes and Mn(II) concentrations (Archibald and Fridovich, 1982; Nico et al., 2002; Hansard et al., 2011; Learman et al., 2011a), we hypothesized that the latter explanation was responsible for the lack of Mn oxide formation.

Indeed, when catalase, a protein that catalyzes the decomposition of $\mathrm{H}_{2} \mathrm{O}_{2}$ to $\mathrm{H}_{2} \mathrm{O}$ and $\mathrm{O}_{2}$ (reaction 7) was added to the reaction, oxidized Mn was detected (Figure 1) and the ASW obtained a brown hue hinting at the presence of Mn oxide minerals (verified with LBB, see mineral discussion below and Figures 4 and 5).

$$
\mathrm{H}_{2} \mathrm{O}_{2} \stackrel{\text { catalase }}{\longrightarrow} \mathrm{H}_{2} \mathrm{O}+1 / 2 \mathrm{O}_{2}
$$

Mn oxide precipitation was negated when the catalase enzyme was boiled prior to addition, thus removing its catalytic activity (Figure 1). These results indicate that the enzymatic ability of the catalase to degrade $\mathrm{H}_{2} \mathrm{O}_{2}$ was requisite for $\mathrm{Mn}$ oxide formation. Mn oxide formation was not observed upon addition of other general (non-functional) proteins (e.g., BSA) or amino acids (e.g., casamino acids; Figure 1), ruling out the possibility of a non-specific protein or amino acid effect. Molecular oxygen 
is generated through the degradation of hydrogen peroxide by catalase (reaction 7) and thus it may be suggested that increased oxygen concentration could increase the propensity for $\mathrm{Mn}$ (II) oxidation. Yet, when SOD, an enzyme that scavenges superoxide and produces molecular oxygen and hydrogen peroxide (reaction 8 ), was added in the presence of catalase (a condition that would result in the highest molecular oxygen concentrations tested here), Mn oxide formation again was not observed (Figure 1).

$$
2 \mathrm{O}_{2}^{-}+2 \mathrm{H}^{+} \rightarrow \mathrm{O}_{2}+\mathrm{H}_{2} \mathrm{O}_{2}
$$

Taken together, these results reveal that both the presence of superoxide and removal of $\mathrm{H}_{2} \mathrm{O}_{2}$ are required for $\mathrm{Mn}$ oxide formation. The product of $\mathrm{Mn}(\mathrm{II})$ reaction with superoxide, $\mathrm{H}_{2} \mathrm{O}_{2}$, likely inhibits the formation of $\mathrm{Mn}$ oxides. This inhibition is likely due to a back reaction between $\mathrm{Mn}$ (III) and $\mathrm{H}_{2} \mathrm{O}_{2}$ (reaction 3) as observed previously (Archibald and Fridovich, 1982) but could also be a result of thermodynamic inhibition by increased $\mathrm{H}_{2} \mathrm{O}_{2}$ levels. Either way, scavenging of $\mathrm{H}_{2} \mathrm{O}_{2}$ is a requisite step in the formation of $\mathrm{Mn}$ oxides by superoxide reaction with $\mathrm{Mn}$ (II).

Measuring loss of $\mathrm{Mn}$ (III) under these conditions is complicated by the need to complex $\mathrm{Mn}$ (III) to measure it spectrophotometrically (Webb et al., 2005b; Madison et al., 2011), yet these complexes will impact the kinetics of superoxide reaction with $\mathrm{Mn}(\mathrm{II})$ and the reaction progression to Mn oxides. Reactions conducted in the presence of complexing ligands (see below), however, confirm that $\mathrm{Mn}$ (III) is formed upon reaction of $\mathrm{Mn}(\mathrm{II})$ and superoxide as predicted and demonstrated previously (Archibald and Fridovich, 1982; Learman et al., 2011a).

We can estimate the concentration of $\mathrm{H}_{2} \mathrm{O}_{2}$ maintained by the catalase in our system with a simple steady-state calculation. A unit of catalase is defined as the amount capable of degrading $1 \mu$ mole of $\mathrm{H}_{2} \mathrm{O}_{2}$ per minute at $\mathrm{pH} 7$ at $25^{\circ} \mathrm{C}$ in the presence of $50 \mu \mathrm{M} \mathrm{H}_{2} \mathrm{O}_{2}$ (Sigma-Aldrich). Since catalase has a very high half-saturation constant ( $1 \mathrm{M}$; Ogura, 1955), we can assume that the rate of $\mathrm{H}_{2} \mathrm{O}_{2}$ degradation is first order with respect to both catalase and $\mathrm{H}_{2} \mathrm{O}_{2}$ concentration. From the definition of a unit, we calculate a second-order rate constant of $2 \times 10^{-5} \mathrm{U} \mathrm{L}^{-1} \mathrm{~min}^{-1}$, neglecting the slight difference between our reaction temperature at $25^{\circ} \mathrm{C}$. The concentration of catalase added to our systems at $t=0$ was $2 \times 10^{5} \mathrm{U} \mathrm{L}^{-1}$, giving a pseudo-first order decay rate coefficient of $4 \mathrm{~min}^{-1}$. Equating the initial rate of $\mathrm{H}_{2} \mathrm{O}_{2}$ production (estimated as equal to the rate of superoxide production from $1 \mathrm{mM}$ SOTS at room temperature; Heller and Croot, 2010) with its rate of decay, we obtain

$$
360 \mathrm{nMmin}^{-1}=4 \min ^{-1}\left[\mathrm{H}_{2} \mathrm{O}_{2}\right]
$$

Thus, the catalase in this system will keep $\mathrm{H}_{2} \mathrm{O}_{2}$ levels below $\sim 90 \mathrm{nM}$, which allows the precipitation of $\mathrm{Mn}$ oxides. In contrast, without catalase, $\mathrm{H}_{2} \mathrm{O}_{2}$ would be expected to build up to a concentration exceeding several micromolar within $10 \mathrm{~min}$.

\section{Mn OXIDE FORMATION IN THE PRESENCE OF COMPLEXING LIGANDS}

In light of the results described above, the stability and/or preservation of $\mathrm{Mn}$ (III) has a direct bearing on the formation of Mn oxide minerals generated from reactions between aqueous $\mathrm{Mn}$ (II) and superoxide. Thus, the presence of organic or inorganic ligands that complex $\mathrm{Mn}$ (III) may result in enhanced stabilization of $\mathrm{Mn}$ (III) to resist back reaction with $\mathrm{H}_{2} \mathrm{O}_{2}$ and allow for Mn oxide formation. Citrate and pyrophosphate have the demonstrated abilities to complex and stabilize aqueous Mn(III) (Klewicki and Morgan, 1998; Webb et al., 2005b). Indeed, the addition of pyrophosphate $(0.5 \mathrm{mM})$ and citrate $(0.5$ and $5.0 \mathrm{mM})$ to the SOTS-Mn(II)catalase reaction significantly $(p<0.05)$ increased the LBB signal (Figure 2A). Once again, Mn(III/IV) was not detected in the absence of catalase. These results suggest that pyrophosphate and citrate played a role in stabilizing $\mathrm{Mn}$ (III), but did not eliminate the inhibition of net $\mathrm{Mn}$ (III) formation by high $\mathrm{H}_{2} \mathrm{O}_{2}$. Further, addition of humic acids also increased the formation of oxidized $\mathrm{Mn}$ relative to the control (catalase only; Figure $2 \mathrm{~A}$ ). All reactions were conducted in the dark, eliminating light-induced electron transfer reactions.

In addition, complexation by citrate appeared to accelerate the reaction of $\mathrm{Mn}$ (II) with superoxide. $10 \mu \mathrm{M}$ of the superoxide scavenger SOD, sufficient to eliminate Mn oxidation in the absence of ligands (Figure 1), decreased the amount of $\mathrm{Mn}$ (II) oxidized in the presence of citrate and catalase by only ca. $40 \%$ relative to that in the absence of SOD, while $50 \mu \mathrm{M}$ decreased $\mathrm{Mn}$ (II) oxidation by more than 90\% (Figure 2B). No oxidation was observed in the absence of SOTS (the superoxide source). This indicates that superoxide was still the sole oxidant of Mn(II), but that the reaction of $\mathrm{Mn}$ (II)-citrate with superoxide is faster than the reaction of uncomplexed $\mathrm{Mn}$ (II), requiring more SOD to outcompete $\mathrm{Mn}$ for the superoxide. This also indicates that oxidation of $\mathrm{Mn}$ (II)-citrate complexes by molecular oxygen or direct electron transfer as observed previously (Klewicki and Morgan, 1998) was not important on the time scale of our experiments. Thus similar to conditions in the absence of citrate, both the presence of superoxide and elimination of hydrogen peroxide are required for net $\mathrm{Mn}(\mathrm{II})$ oxidation under these experimental conditions.

Yet, although more oxidized Mn was observed in the presence of organic ligands, a lower proportion was present as a solidphase, based both on the appearance of the solutions and on absorbance measurements. The reacted solutions in the absence of (in)organic ligands were darker (more brown) than equivalent conditions in the presence of those same ligands (Figure 2C), implying lower concentrations of Mn oxide colloids in the latter case (see discussion of solid-phases below). Under non-Mn oxide forming conditions, that is, in the absence of catalase, background absorbance at $700 \mathrm{~nm}$ for SOTS reaction with $\mathrm{Mn}$ (II) ranged from 0.001 to 0.004 , including conditions containing citrate, pyrophosphate, and humic acids (Figure 2C). In contrast, the absorbance signal (caused mostly by light scattering) from colloidal Mn oxides formed upon reaction of SOTS and Mn(II) in the presence of catalase was 0.182 but was an order of magnitude lower in the presence of citrate $(0.018)$, pyrophosphate $(0.012)$ and humic acids (0.016), again indicating lower Mn oxide content. Furthermore, when solutions containing both catalase and citrate were centrifuged to decrease the contribution of colloidal $\mathrm{Mn}$ to the absorbance signal, a strong absorbance peak at $430 \mathrm{~nm}$ indicative of a Mn(III)-citrate complex (Klewicki and Morgan, 1998) appeared (Figure 3A). As to be expected, this complex was only observed in the presence of citrate. 

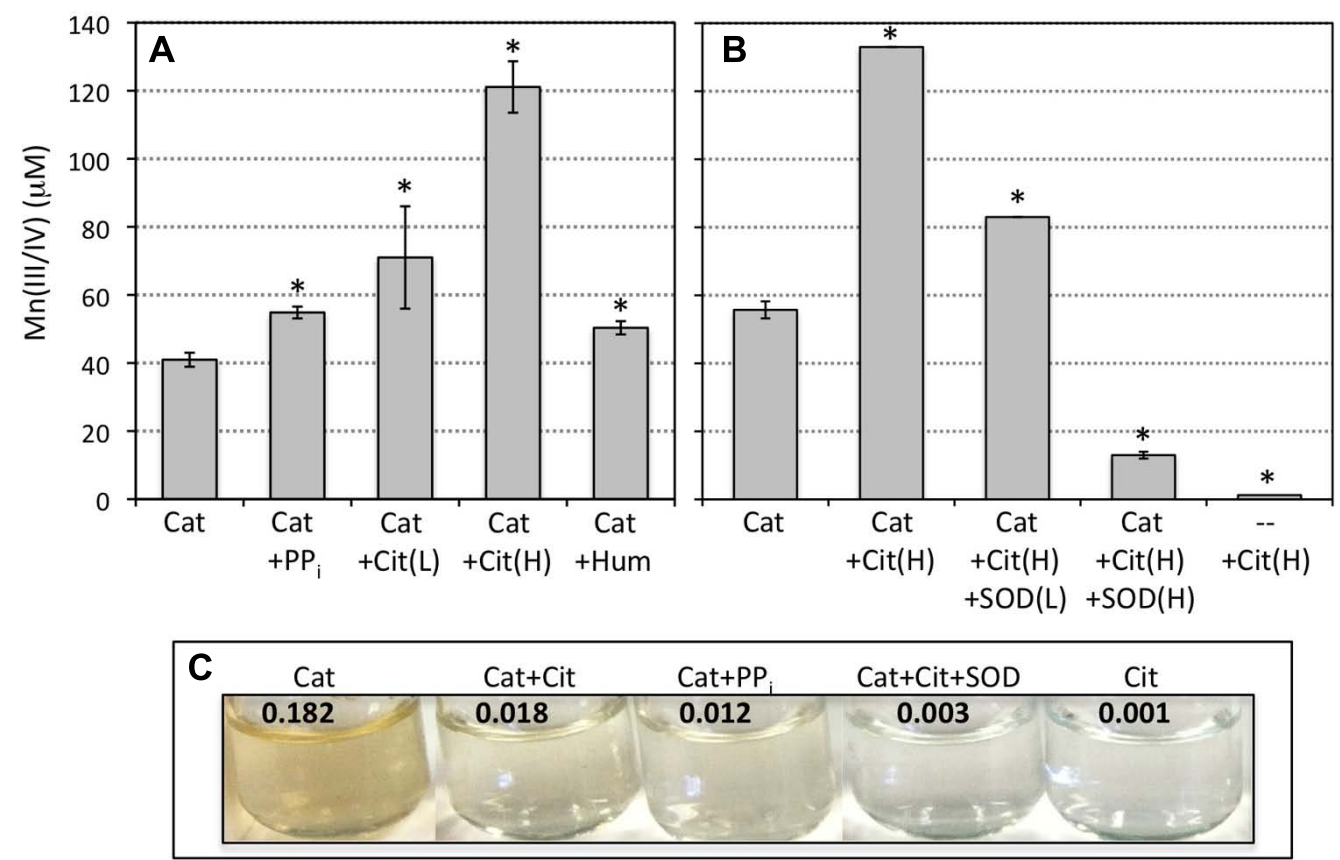

FIGURE 2 | (A) Abiotically produced superoxide (1 $\mathrm{mM}$ SOTS) reacted with $\mathrm{Mn}(\mathrm{II})(200 \mu \mathrm{M})$ in the absence and presence of catalase (Cat) and pyrophosphate $\left(0.5 \mathrm{mM} ; \mathrm{PP}_{j}\right)$, citrate $(0.5$ and $5 \mathrm{mM}$, Cit $(\mathrm{L})$ and $\mathrm{Cit}(\mathrm{H})$, respectively) or humic acids $(10 \mathrm{mg} / \mathrm{L})$. (B) Abiotically produced superoxide reacted with $\mathrm{Mn}(\mathrm{II})$ in the presence of $5 \mathrm{mM}$ citrate and catalase and/or SOD $(10$ and $50 \mu \mathrm{M})$. Measurements are presented as the sample mean \pm SD for replicate samples $(n=3)$. Asterisks indicate treatments that significantly $(p<0.05)$ differ based on the Student's $t$-test (unpaired, two-tailed) from the control condition (catalase only). Brackets for SDs below 3\% of the mean value are smaller than the width of the line. Intra-experiment variability was low (as evidenced by the low SDs) but there was slight inter-experiment variability due to minor deviations in reaction time, temperature in the lab, and SOTS concentration. Individual experiments are plotted separately for direct comparison to the corresponding control condition for each experiment. (C) Pictures depict the color of a subset of the reacted solutions following $24 \mathrm{~h}$ of reaction. The numbers at the top of pictures indicate the visible light absorbance at $700 \mathrm{~nm}$, which is indicative of the Mn oxide colloid contribution. Background absorbance for SOTS reaction with $200 \mu \mathrm{M} \mathrm{Mn(II)} \mathrm{in} \mathrm{the} \mathrm{absence} \mathrm{of}$ catalase is 0.001 .
A

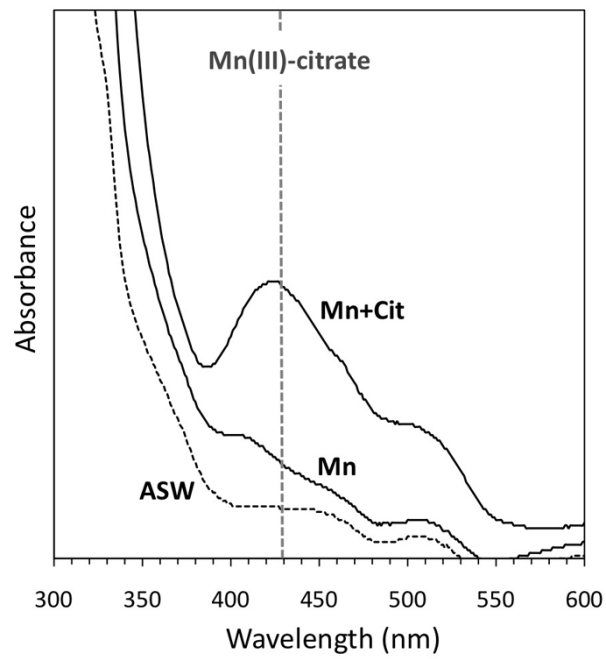

FIGURE 3 | (A) UV-visible absorbance scan (300-600 nm) for solutions containing solely ASW + catalase (ASW), ASW + Mn(II) + catalase (Mn), and ASW $+\mathrm{Mn}(\mathrm{II})+$ catalase $+5 \mathrm{mM}$ citrate $(\mathrm{Mn}+$ cit). All $\mathrm{Mn}$ (II) concentrations are $200 \mu \mathrm{M}$ and all solutions contain SOTS. Vertical dotted line illustrates the absorbance wavelength for $\mathrm{Mn}$ (III)-citrate complexes. Solutions were centrifuged before scanning to remove the contribution of $\mathrm{Mn}$ oxide colloids
B

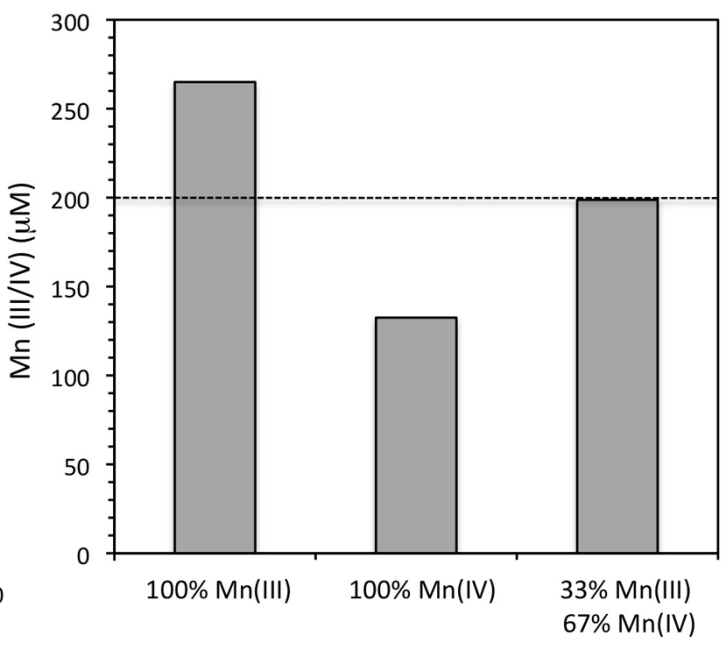

to the absorbance. (B) Oxidized Mn concentrations calculated from the LBB measurement. If we assume oxidized $\mathrm{Mn}$ is solely $\mathrm{Mn}$ (III) (left-most bar), the total oxidized $\mathrm{Mn}$ is higher than the initial $\mathrm{Mn}(\mathrm{II})$ present in the system. A mixture of $\mathrm{Mn}(\mathrm{III})$ and $\mathrm{Mn}(\mathrm{IV})$ gives a total concentration of oxidized $\mathrm{Mn}$ in between these extremes. The rightmost bar illustrates that a mixture of $33 \%$ $\mathrm{Mn}(\mathrm{III})$ and $67 \% \mathrm{Mn}(\mathrm{IV})$ corresponds to oxidation of all the initial $\mathrm{Mn}(\mathrm{II})$ ). 

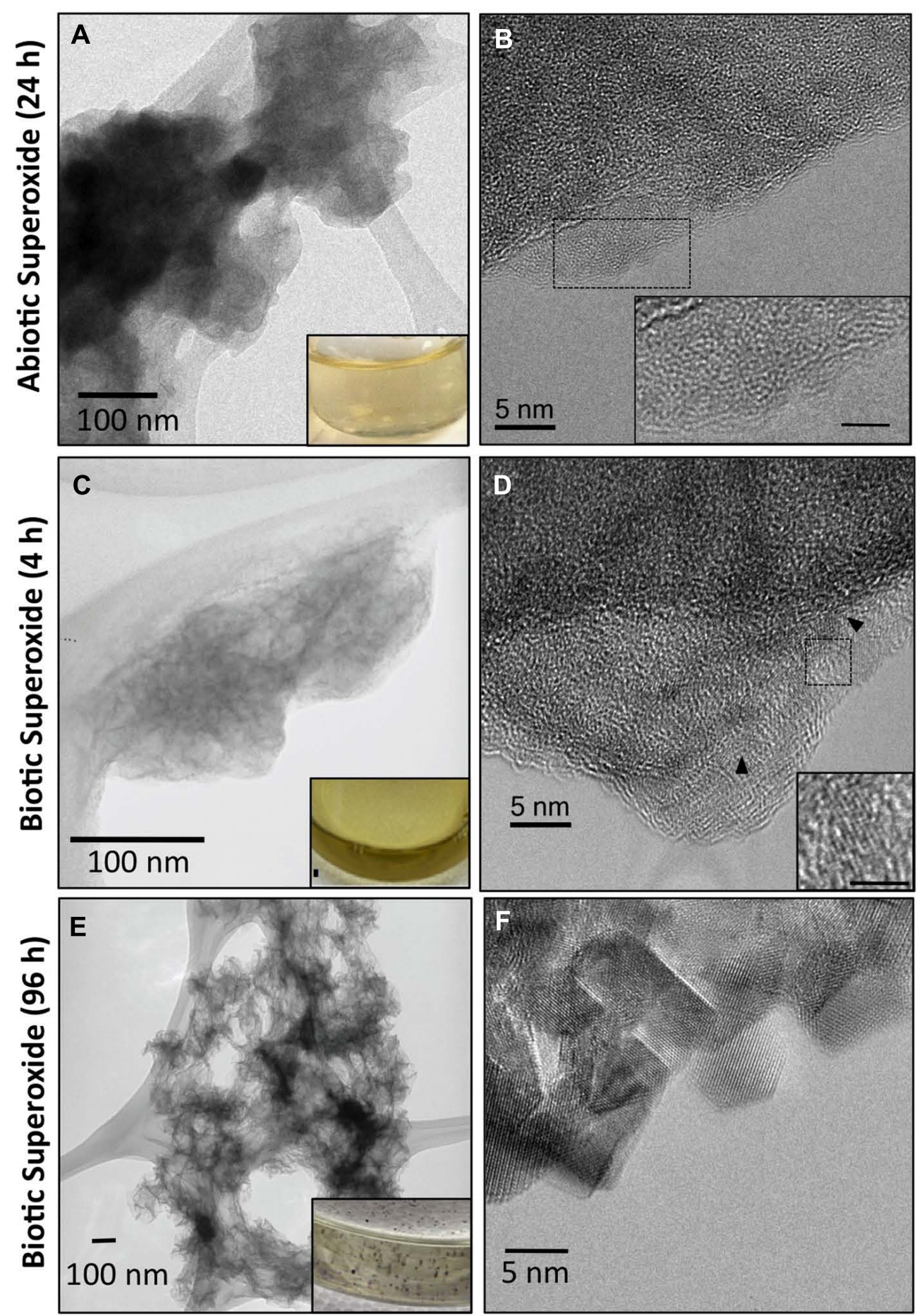

FIGURE 4 | Transmission electron microscopy (TEM) images (A,C) illustrating small dispersed, colloidal Mn oxides formed via oxidation of $\mathrm{Mn}$ (II) by abiotically (A) and biotically generated (C) superoxide and 24 and $\mathbf{4 h}$, respectively. TEM images of $\mathrm{Mn}$ oxides formed by biotic superoxide after $96 \mathrm{~h}$ show mineral particle aggregates (E). Texture underneath the particles is due to the lacey-carbon support film. Insets in $(\mathbf{A}, \mathbf{C}, \mathbf{E})$ are pictures of the reacted solution appearance. Biotic superoxide $\mathrm{Mn}$ oxides were formed via reaction of superoxide-generating microbial cell-free filtrate with $\mathrm{Mn}(\mathrm{II})$ as described in detail previously (images modified from Learman et al., 2011b). High resolution TEM (B,D,F) demonstrating poor crystallinity of the superoxide-produced $\mathrm{Mn}$ oxides with a lack of discernable lattice fringes in abiotic generated $\mathrm{Mn}$ oxides (B) and small $(\sim 5 \mathrm{~nm})$ crystalline domains in biotic Mn oxides (D). HR-TEM images of Mn oxides formed by biotic superoxide after $96 \mathrm{~h}$, however, show defined crystalline domains (F). Insets in (B,D) illustrate the difference in crystallinity (scale bar $=2 \mathrm{~nm}$ ). 


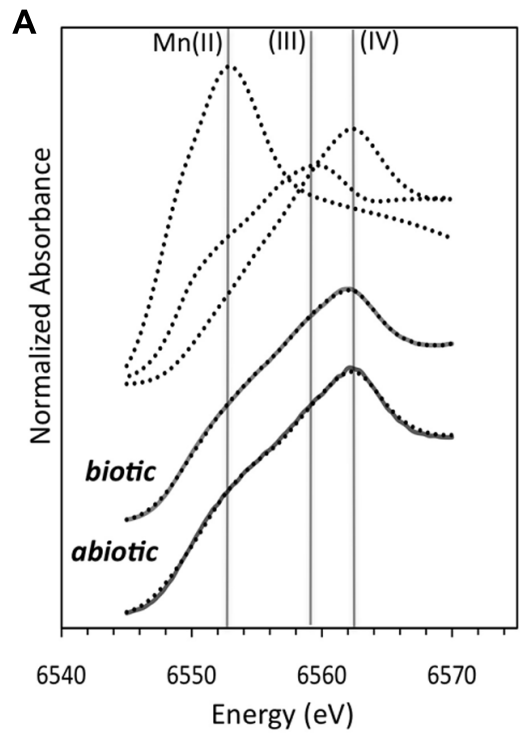

FIGURE 5 | (A) Mn K-edge XANES spectra of the Mn oxides produced from biotically produced $\mathrm{Mn}$ oxides after $4 \mathrm{~h}$ (after Learman et al., 2011b) and abiotically produced $\mathrm{Mn}$ oxides. The dotted lines represent the standards for $\mathrm{Mn}(\mathrm{IV})\left(\delta-\mathrm{MnO}_{2}\right), \mathrm{Mn}(\mathrm{III})$ (feitknechtite, $\left.\beta-\mathrm{MnOOH}\right)$, and $\mathrm{Mn}(\mathrm{II})\left(\mathrm{MnCl}_{2}\right.$; as described in Bargar et al., 2005). The solid gray line is the linear combination fit (LCF) using the three Mn standards to represent the three oxidation states.

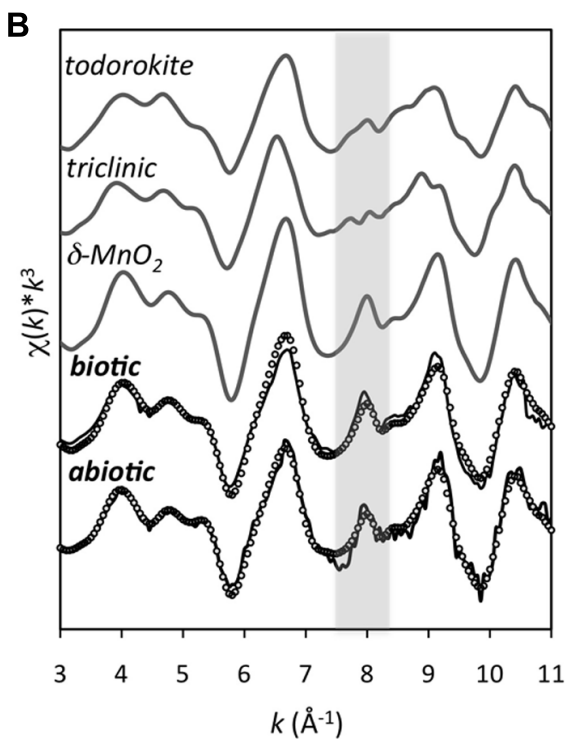

(B) $k^{3}$-weighted Mn EXAFS spectra (solid line) and linear-combination fit (dotted line) for the biotically and abiotically produced Mn oxides. The gray shaded area highlights the "indicator region" emphasizing the spectral differences that can be used to distinguish hexagonal (as $\delta$ - $\mathrm{MnO} 2$ ) from both triclinic birnessite (labeled triclinic) and todorokite (as described in Webb etal., 2005a).
However, all oxidized Mn could not have been present as $\mathrm{Mn}(\mathrm{III})$ as in that case the oxidized Mn measured by LBB would exceed $(\sim 260 \mu \mathrm{M})$ the total $\mathrm{Mn}$ added $(200 \mu \mathrm{M})$ to the reaction containing $5 \mathrm{mM}$ citrate (Figure 3B). We can calculate the maximum possible amount of $\mathrm{Mn}$ (III) that could have formed by assuming that all of the $\mathrm{Mn}$ (II) oxidized either to $\mathrm{Mn}(\mathrm{III})$ or to $\mathrm{Mn}(\mathrm{IV})$; in this case, final concentrations of $65 \mu \mathrm{M}(33 \%)$ of $\mathrm{Mn}(\mathrm{III})$ and $135 \mu \mathrm{M}(67 \%) \mathrm{Mn}(\mathrm{IV})$ would be more consistent with the measured LBB signal in the presence of $5 \mu \mathrm{M}$ citrate (Figure 2). Together, this evidence suggests that in the presence of citrate, both $\mathrm{Mn}$ (III)-citrate complexes and Mn oxide colloids are present. This is consistent with the results of Klewicki and Morgan (1998), who found that Mn(III)-citrate complexes could disproportionate to form Mn oxide precipitates.

Citrate has redox active properties and can induce Mn oxide reductive dissolution (Wang and Stone, 2006). This reaction can lead to redox cycling of $\mathrm{Mn}$ at the $\mathrm{Mn}$ oxide surface producing $\mathrm{Mn}(\mathrm{II})$ and ultimately $\mathrm{Mn}(\mathrm{III})$-citrate. Thus, following the initiation of $\mathrm{Mn}$ oxide precipitation, reactions between citrate and the Mn oxide surface may also contribute to the preferential accumulation of $\mathrm{Mn}$ (III)-citrate complexes over Mn oxide particles observed here (Figures 2 and 3 ). This contribution would increase as the concentration of citrate increases (Wang and Stone, 2006). However, this mechanism cannot be the sole source of $\mathrm{Mn}$ (III)-citrate in our systems, since it would not explain our observations that much more $\mathrm{Mn}$ is oxidized in the presence of citrate than in its absence, and that the effectiveness of SOD in quenching $\mathrm{Mn}$ oxide formation is decreased in the presence of citrate. In addition, higher concentrations of oxidized Mn yet lower Mn oxide precipitation were also observed in the presence of pyrophosphate (Figure 2) which does not have these redox-active properties, further supporting a role for $\mathrm{Mn}(\mathrm{III})$ complexation in the net accumulation of oxidized $\mathrm{Mn}$ in the presence of ROS.

\section{CHARACTERISTICS OF SUPEROXIDE-GENERATED Mn OXIDES}

In the presence of catalase, reactions between $\mathrm{Mn}$ (II) and superoxide led to a discoloration of the ASW from clear to light brown (Figure 2C), indicative of Mn oxide formation as quantified by LBB (see Figure 1). These Mn oxides were harvested (24 h of reaction) by centrifugation (see Materials and Methods) resulting in a thin brown film on the centrifuge tube wall. TEM revealed that the brown film was composed of small, dispersed colloidal Mn oxides averaging 100-125 nm in diameter with no evidence of aggregation (Figure 4A). The interiors of the oxide grains appeared highly disordered and discernable lattice fringes were not observed via high resolution TEM (HR-TEM) imaging, indicating that the oxides were very poorly crystalline, if not "amorphous" (Figure 4B). The lack of lattice fringes suggested the particles were strained, perhaps attributable in part to a poorly ordered distribution of interlayer cations. These poorly crystalline colloidal Mn oxides were stable under these conditions, and ripening or aggregation-based growth was not observed following several days at room temperature (see below).

The Mn oxides were composed of a poorly ordered, poorly crystalline phyllomanganate with hexagonal symmetry and low $\mathrm{Mn}(\mathrm{III})$ content, similar to $\delta-\mathrm{MnO}_{2}$ (Figure 5). The energy position of the XANES absorbance maximum for the abiotic Mn oxide centers around $6562 \mathrm{eV}$. This position is consistent with the absorbance maximum of $\delta-\mathrm{MnO}_{2}$, which has an average 
oxidation state of 3.9-4.0, suggesting that the oxides are dominated by $\mathrm{Mn}(\mathrm{IV})$. LCF of the XANES spectra using $\delta-\mathrm{MnO}_{2}$, feitknechtite $(\beta-\mathrm{MnOOH})$, and $\mathrm{MnCl}_{2}$ indicated approximate relative percentages of $\mathrm{Mn}(\mathrm{IV}), \mathrm{Mn}(\mathrm{III})$, and $\mathrm{Mn}(\mathrm{II})$ as 82,5 , and $13 \%$, respectively (Figure 5; $R$-factor $=0.07$ ) - yet, due to the difficulty in assigning a specific binding energy to $\mathrm{Mn}$ (III), the values obtained should be taken as approximate values. The Mn K-edge EXAFS spectrum of the abiotic Mn oxides could be fully reconstructed with solely $\delta-\mathrm{MnO}_{2}$ by LCF (Figure 5; $R$-factor $=0.05$ ). Indeed, visual examination of the $\mathrm{Mn} \mathrm{K}$-edge spectral fingerprints for model compounds of the three most common biogenic oxides (Figure 5) illustrate differences in the features at 6.8, 8.0 (the "indicator" region), and $9.3 \AA^{-1}$, which are diagnostic of phyllomanganates (McKeown and Post, 2001). In particular, while hexagonal birnessite (as $\delta-\mathrm{MnO}_{2}$ in Figure 5) has a distinct sharp peak at $\sim 8 \AA^{-1}$, a decrease in the amplitude of this oscillation and a broadening of the feature at $\sim 9 \AA^{-1}$ is consistent with an increase in the triclinic birnessite and/or todorokite content (McKeown and Post, 2001; Gaillot et al., 2003; Manceau et al., 2004; Webb et al., 2005a). Here, the EXAFS spectrum for the abiotic Mn oxide has a shoulder at $6.8 \AA^{-1}$, one sharp peak at $8.0 \AA^{-1}$, and a sharp peak at $9.3 \AA^{-1}$, all characteristic of hexagonal birnessite (Gaillot et al., 2003; Manceau et al., 2004).

Interestingly, the abiotic Mn oxides observed here are structurally similar to those produced biotically by a large taxonomically diverse group of organisms (fungi and bacteria) that likely employ different enzymatic and oxidation pathways (Jurgensen et al., 2004; Bargar et al., 2005; Webb et al., 2005a; Grangeon et al., 2010). In fact, the Mn oxides formed here in a purely abiotic superoxide system were similar to those previously characterized upon reaction of $\mathrm{Mn}$ (II) with superoxide-generating microbial exudate (cell-free filtrate). The biotic oxides were formed by reacting $\mathrm{Mn}$ (II) for $4 \mathrm{~h}$ with the superoxide-generating cell-free filtrate produced by Roseobacter AzwK-3b grown in an organic carbon replete medium (K media, pH 7.6; Learman et al., 2011b). Similar to the abiotic oxides, the Mn K-edge EXAFS spectra of the biogenic Mn oxides were fully reconstructed with solely $\delta$ $\mathrm{MnO}_{2}$ (Figure 5; Learman et al., 2011b). In comparison to the abiotic Mn oxides, however, the oxides formed by superoxide generated microbial filtrate contained a higher relative proportion of $\mathrm{Mn}(\mathrm{III})$, with approximate values being $8 \% \mathrm{Mn}(\mathrm{II}), 21 \%$ Mn(III), and 71\% Mn(IV) (Learman et al., 2011b). In addition, the biotically generated superoxide had discrete crystalline domains - albeit small with lattice fringes continuous only over regions less than $5 \mathrm{~nm}$ (Figure 4D; Learman et al., 2011b). The coherent scattering domains of the biogenic oxides are rotated in a nearly continuous distribution of orientations indicating a high degree of disorder (Figure 4D), only slightly more ordered than the abiotic analogs. These crystallinity differences cannot be attributed simply to aging since the biogenic Mn oxides were in fact younger $(4 \mathrm{~h})$ than the abiotically generated $\mathrm{Mn}$ oxides $(24 \mathrm{~h})$.

Despite the similarity of initial Mn oxides, the geochemical conditions within which the $\mathrm{Mn}(\mathrm{II})$ and superoxide react influences ripening and aggregation of the oxides to more crystalline, ordered phases. After several days of reaction between $\mathrm{Mn}$ (II) and abiotically generated superoxide, the cloudy brown color indicative of the colloidal Mn oxides remained unchanged and visible Mn oxide particles and/or aggregates were not observed. In contrast, when $\mathrm{Mn}$ (II) reacted with biogenic superoxide within cell-free microbial filtrate, the brown hue disappeared after $96 \mathrm{~h}$ and Mn oxide minerals were clearly visible by eye, with particle size continuing to grow over time (Figure 4; Learman et al., 2011b). Indeed, well-defined lattice fringes were apparent in nearly every region of the grain, although micron-sized grains were aggregates of crystallites ranging from five to tens of nanometers in diameter. In light of the similar initial Mn oxide products, the ability of the superoxide generated Mn oxide colloids to undergo aggregated crystal growth apparently requires another reactant that is present within the microbial exudate and may include individual or complex proteins, organic metabolites, or extracellular organic polymers. This organic-mediated aggregation could lead to the large morphological diversity of structurally similar Mn oxides formed under various biological conditions (e.g., fungi, bacteria, cell-free filtrates; Emerson et al., 1989; van Waasbergen et al., 1996; Villalobos et al., 2003; Tebo et al., 2004; Toner et al., 2005; Miyata et al., 2006a; Learman et al., 2011b; Santelli et al., 2011; Tang et al., 2013). Further, the mineral associated organics may lead to the observed higher proportion of Mn(III) within the biogenic oxides compared to the abiotically generated oxides.

\section{CONCLUSION}

This work provides the first direct evidence that, under conditions relevant to natural waters, oxidation of $\mathrm{Mn}$ (II) by superoxide can occur and lead to formation of Mn oxides. These results are consistent with previous observations of Mn oxide formation during photo-oxidation of humic substances (Nico et al., 2002), where we suspect the humic material also served to stabilize $\mathrm{Mn}$ (III) to allow for oxide precipitation. Our data also indicate that $\mathrm{H}_{2} \mathrm{O}_{2}$ inhibits $\mathrm{Mn}$ oxidation, possibly because the intermediate $\mathrm{Mn}$ oxidation product, $\mathrm{Mn}(\mathrm{III})$, rapidly oxidizes $\mathrm{H}_{2} \mathrm{O}_{2}$, regenerating $\mathrm{Mn}$ (II) (e.g., reaction 3). Finally, we have demonstrated here that the presence of (in)organic ligands can increase the yield of oxidized Mn but decreases net oxide formation, likely by stabilizing Mn(III). Recent studies have highlighted the ubiquity and abundance of $\mathrm{Mn}(\mathrm{III})$-ligand complexes in aqueous and sedimentary environments (Trouwborst et al., 2006; Madison et al., 2011). The reaction of $\mathrm{Mn}$ (II) with superoxide is one possible source of these complexes and their formation and stability will ultimately impact the precipitation of $\mathrm{Mn}$.

Could reaction between superoxide and $\mathrm{Mn}(\mathrm{II})$ represent a source of $\mathrm{Mn}$ oxide minerals in environmental systems? Our results indicate that one question to consider is whether $\mathrm{H}_{2} \mathrm{O}_{2}$ levels remain sufficiently low for oxide formation in the presence of superoxide. The highest production rates of both superoxide and $\mathrm{H}_{2} \mathrm{O}_{2}$ are expected in sunlit-irradiated surface waters rich in natural organic matter. Even in such waters, $\mathrm{H}_{2} \mathrm{O}_{2}$ concentrations generally remain smaller than $1 \mu \mathrm{M}$ (Scully et al., 1995; Richard et al., 2007), close to the conditions created in our experimental systems by adding catalase. Thus, while both $\mathrm{Mn}$ (II) concentrations and superoxide fluxes created by ultraviolet (UV)-oxidation of natural organic matter are lower than those in our experimental systems, it seems plausible that Mn oxide formation by superoxide could occur in sunlit natural waters. However, since 
photoreduction of Mn oxides is also known to occur (Sunda and Huntsman, 1994), the net effect of light is not necessarily Mn oxidation.

In the absence of UV light such as in deep waters and soils, both superoxide production and $\mathrm{H}_{2} \mathrm{O}_{2}$ production and decay will be controlled by biological activity (Rose et al., 2008; Hansard et al., 2010; Vermilyea et al., 2010) and reactions with metals, such as Fe (Rose and Waite, 2002; Burns et al., 2010). Our results indicate that as long as these processes result in both superoxide production and net $\mathrm{H}_{2} \mathrm{O}_{2}$ decay, $\mathrm{Mn}$ oxides could precipitate. Indeed, pure isolates of common marine bacteria (Learman et al., 2011a) and both marine and soil fungi (Hansel et al., 2012; Tang et al., 2013) have been found which meet these minimum requirements and are capable of oxidative precipitation of $\mathrm{Mn}$ via the formation of extracellular superoxide. The results provided here may point to other microbially mediated processes occurring, however, to allow for Mn oxide formation, in particular enzymatic hydrogen peroxide degradation and/or production of organic metabolites and/or polymers that can function as Mn complexing ligands.

In addition to the factors discussed above, the importance of superoxide-based Mn oxide formation in environmental systems will depend on the rate constant of the initial reaction (reaction 1) and on the concentration of superoxide present. Hansard et al. (2011) have shown that under seawater conditions, the reaction is sufficiently fast, and superoxide sufficiently abundant, to oxidize $\mathrm{Mn}(\mathrm{II})$ on a time scale on the order of hours. The same study found a similarly fast reaction rate for simulated freshwater conditions, but a time scale for $\mathrm{Mn}$ (II) oxidation for these conditions could not be calculated since superoxide concentrations in freshwaters are unknown. Superoxide has also not yet been quantified in soils and sedimentary environments, but could be formed both by biological activity and by redox reactions such as the oxidation of Fe(II) (Rose and Waite, 2002; Burns et al., 2010).

Another factor affecting the importance of superoxide to $\mathrm{Mn}$ oxide formation is the extent to which the $\mathrm{Mn}$ (III) produced by reaction 1 is re-reduced instead of being further oxidized. Hansard et al. (2011) observed evidence for a Mn(II/III) cycle in their seawater experiments, possibly because of reduction of $\mathrm{Mn}$ (III) by superoxide. Some organic compounds may also be able to react with the oxidized Mn intermediates, regenerating $\mathrm{Mn}(\mathrm{II})$ and thus

\section{REFERENCES}

Aguirre, J., Rios-Momberg, M., Hewitt, D., and Hansberg, W. (2005). Reactive oxygen species and development in microbial eukaryotes. Trends Microbiol. 13, 111-118. doi: 10.1016/j.tim.2005.01.007

Archibald, F. S., and Fridovich, I. (1982). The scavenging of superoxide radical by manganous complexes: in vitro. Arch. Biochem. Biophys. 214, 452-463. doi: 10.1016/00039861(82)90049-2

Bargar, J. R., Tebo, B. M., Bergamann, U., Webb, S. M., Glaetzel, P., Chiu, V. Q., et al. (2005). Biotic and abiotic products of $\mathrm{Mn}$ (II) oxidation by spores of the marine Bacillus sp.

preventing Mn oxide formation. Even if no Mn oxide accumulates, the rapid formation and turnover of reactive intermediate Mn species may have vast implications for the redox cycling of other (in)organic compounds, somewhat analogous to the recently revealed "cryptic" sulfur cycle (Canfield et al., 2010). Further, this rapidly spinning Mn cycle could have a substantial influence on the concentrations of superoxide and hydrogen peroxide in surface waters.

A final finding of this study was that the ensuing poorly ordered, nanocrystalline birnessite products formed upon superoxidemediated Mn(II) oxidation are similar to Mn oxides formed by various organisms, including bacteria and fungi, that employ different mechanisms of Mn(II) oxidation (Villalobos et al., 2003; Tebo et al., 2004, 2005; Bargar et al., 2005; Webb et al., 2005a,b; Miyata et al., 2006a,b; Santelli et al., 2011). Further, the similarity in Mn oxide structure here implies that Mn oxide products may not carry an obvious signature of the process responsible for superoxide generation (e.g., UV-versus microbially generated superoxide). Nevertheless, it is important to note that despite the fact that the abiotic Mn oxides did not aggregate to larger particulate $\mathrm{Mn}$ oxides over time (i.e., the oxides remained colloidal), Mn oxides formed by biotically generated superoxide within live cell incubations and a cell-free filtrate rapidly formed particulate (visible) Mn oxides. Thus, despite the non-specificity of the initial Mn oxide products to reaction mechanism, observations of particulate Mn oxide minerals and deposits within the environment may point to a biological (or at least organic) influence.

\section{ACKNOWLEDGMENTS}

Portions of this research were carried out at the Stanford Synchrotron Radiation Lightsource (SSRL), a national user facility operated by Stanford University on behalf of the US Department of Energy, Office of Basic Energy Sciences. The SSRL Structural Molecular Biology Program is supported by the Department of Energy, Office of Biological and Environmental Research, and by the National Institutes of Health, National Center for Research Resources, Biomedical Technology Program. This project was supported by the National Science Foundation, grants EAR1245919/1025077 (awarded to Colleen M. Hansel and Bettina M. Voelker), and by the Radcliffe Institute for Advanced Study at Harvard University (through a fellowship to Bettina M. Voelker).

radical generation. Environ. Sci. Technol. 44, 7226-7231. doi: 10.1021/ es $903519 \mathrm{~m}$

Cabelli, D. E., and Bielski, B. H J. (1982). Pulse-radiolysis study of the kinetics and mechanisms of the reactions between manganese(II) complexes and $\mathrm{HO}_{2} / \mathrm{O}_{2}^{-}$ radicals. 1. Sulfate, formate, and pyrophosphate complexes. J. Phys. Chem. 88, 3111-3115. doi: 10.1021/ j150658a037

Cabelli, D. E., and Bielski, B. H. J. (1984). Pulse-radiolysis study of the kinetics and mechanisms of the reactions between manganese(II) complexes and $\mathrm{HO}_{2} / \mathrm{O}_{2}^{-}$radicals. 2. The phosphate complex and an overview. J. Phys. Chem. 88, 62916294. doi: 10.1021/j150669a047

Canfield, D. E., Stewart, F. J., Thamdrup, B., De Brabandere, L., Dalsgaard, T., Delong, E. F., et al. (2010). A cryptic sulfur cycle in oxygen-minimum-zone waters off the Chilean coast. Science 330, 1375-1378. doi: 10.1126/science. 1196889

Daly, M. J., Gaidamakova, E. K., Matrosova, V. Y., Vasilenko, A., Zhai, M., Venkateswaran, A., et al. (2004). Accumulation of $\mathrm{Mn}$ (II) in Deinococcus radiodurans facilitates gamma-radiation resistance. Science $306,1025-1028$. doi: $10.1126 /$ science.1103185 
Diaz, J., Hansel, C. M., Voelker, B. M., Mendes, C. M., Andeer, P. F., and Zhang, T. (2013). Widespread production of extracellular superoxide by marine heterotrophic bacteria. Science 340, 1223-1226. doi: 10.1126/science. 1237331

Duckworth, O. W., and Sposito, G. (2005). Siderophore-manganese(III) interactions. I. Air-oxidation of manganese(II) promoted by desferrioxamine B. Environ. Sci. Technol. 39, 6037-6044. doi: 10.1021/es050275k

Emerson, D., Garen, R. E., and Ghiorse, W. (1989). Formation of metallogenium-like structures by a manganese-oxidizing fungus. Arch. Microbiol. 151, 223-231. doi: 10.1007/BF00413134

Gaillot, A. C., Flot, D., Drits, V. A., Manceau, A., Burghammer, M., and Lanson, B. (2003). Structure of synthetic K-rich birnessite obtained by high decomposition of $\mathrm{KMnO}_{4}$. I. Two-layer polytype from 800 degrees C experiment. Chem. Mater. 15, 4666-4678. doi: $10.1021 / \mathrm{cm} 021733 \mathrm{~g}$

Grangeon, S., Lanson, B., Miyata, N., Tani, Y., and Manceau, A. (2010). Structure of nanocrystalline phyllomanganates produced by freshwater fungi. Am. Miner. 95, 1608-1616. doi: 10.2138/am.2010.3516

Hansard, S. P., Easter, H. D., and Voelker, B. M. (2011). Rapid reaction of nanomolar $\mathrm{Mn}(\mathrm{II})$ with superoxide radical in seawater and simulated freshwater. Environ. Sci. Technol. 45, 2811-2817. doi: 10.1021/ es104014s

Hansard, S. P., Vermilyea, A. W., and Voelker, B. M. (2010). Measurements of superoxide radical concentration and decay kinetics in the Gulf of Alaska. Deep Sea Res. Part 1 Oceanogr. Res. Pap. 57, 1111-1119. doi: 10.1016/j.dsr.2010.05.007

Hansel, C. M., and Francis, C. A. (2006). Coupled photochemical and enzymatic $\mathrm{Mn}$ (II) oxidation pathways of a planktonic Roseobacter-like bacterium. Appl. Environ. Microbiol. 72, 3543-3549. doi: 10.1128/AEM.72.5.3543-3549.2006

Hansel, C. M., Zeiner, C. A., Santelli, C. M., and Webb, S. M. (2012). Mn(II) oxidation linked to superoxide production during asexual reproduction in an Ascomycete fungi. Proc. Natl. Acad. Sci. U.S.A. 109, 12621-12625. doi: 10.1073/pnas.1203885109

Heller, M. I., and Croot, P. L. (2010). Application of a superoxide $\left(\mathrm{O}_{2}^{-}\right)$thermal source (SOTS-1) for the determination and calibration of $\mathrm{O}_{2}^{-}$fluxes in seawater. Anal. Chim. Acta 667, 1-13. doi: 10.1016/j.aca.2010.03.054
Ingold, K. U., Paul, T., Young, M. J., and Doriron, L. (1997). Invention of the first azo compound to serve as a superoxide thermal source under physiological conditions: concept, synthesis and chemical properties. J. Am. Chem. Soc. 119, 1236412365. doi: $10.1021 /$ ja9728861

Jenne, E. A. (1968). "Controls on Mn, $\mathrm{Co}, \mathrm{Ni}, \mathrm{Cu}$, and $\mathrm{Zn}$ concentrations in soil and water: the significant role of hydrous $\mathrm{Mn}$ and Fe oxides," in Trace Inorganics in Water, ed. R. F. Gould (Washington, DC: American Chemical Society), 337-387.

Johnson, D., and Chiswell, B. (1993). A new method for the evaluation of the oxidizing equivalent of manganese in surface freshwaters. Talanto 40, 533-540. doi: 10.1016/00399140(93)80013-H

Junta, J. L., and Hochella, M. F. Jr. (1994). Manganese(II) oxidation at mineral surfaces: a microscopic and spectroscopic study. Geochim. Cosmochim. Acta 58, 4985-4999. doi: 10.1016/0016-7037(94)90226-7

Jurgensen, A., Widmeyer, J., Gordon, R., Bendell-Young, L., Moore, M., and Crozier, E. (2004). The structure of manganese oxide on the sheath of the bacterium Leptothrix discophora: an EXAFS study. Am. Miner. 89, 1110-1118.

Klewicki, J. K., and Morgan, J. J. (1998). Kinetic behavior of $\mathrm{Mn}$ (III) complexes of pyrophosphate, EDTA and citrate. Environ. Sci. Technol. 32, 2916-2922. doi: 10.1021/es980308e

Krumbein, W. E., and Altmann, H. J. (1973). New method for detection and enumeration of manganese oxidizing and reducing microorganisms. Helgol. Wiss. Meeresunters. 25, 347-356. doi: 10.1007/ BF01611203

Kustka, A. B., Shaked, Y., Milligan, A. J., King, D. W., and Morel, F. M. M. (2005). Extracellular production of superoxide by marine diatoms: contrasting effects on iron redox chemistry and bioavailability. Limnol. Oceanogr. 50, 1172-1180. doi: 10.4319/lo.2005. 50.4.1172

Learman, D. R., Voelker, B. M., VazquezRodriguez, A. I., and Hansel, C. M. (2011a). Formation of manganese oxides by bacterially generated superoxide. Nat. Geosci. 4, 95-98. doi 10.1038/ngeo 1055

Learman, D. R., Wankel, S. D., Webb, S. M., Martinez, N., Madden, A. S., and Hansel, C. M. (2011b). Coupled biotic-abiotic Mn(II) oxidation pathway mediates the formation and structural evolution of biogenic Mn oxides. Geochim.
Cosmochim. Acta 75, 6048-6063. doi: 10.1016/j.gca.2011.07.026

Luther, G. W. III. (2010). The role of one- and two-electron transfer reactions in forming thermodynamically unstable intermediates as barriers in multi-electron redox reactions. Aquat. Geochem. 16, 395-420. doi: 10.1007/s10498-009-9082-3

Madden, A. S., and Hochella, M. F. Jr. (2005). A test of geochemical reactivity as a function of mineral size: manganese oxidation by hematite nanoparticles. Geochim. Cosmochim. Acta 73, 6517-6530.

Madison, A. S., Tebo, B. M., and Luther, G. W. III. (2011) Simultaneous determination of soluble manganese(III), manganese(II) and total manganese in natural (pore)waters. Talanta 84, 374-381. doi: 10.1016/j.talanta.2011.01.025

Manceau, A., Marcus, M. A., Tamura, N., Proux, N. Geoffroy, N., and Lanson, B. (2004). Natural speciation of $\mathrm{Zn}$ at the micrometer scale in a clayey soil using X-ray fluorescence, absorption, and diffraction. Geochim. Cosmochim. Acta 68, 2467-2483. doi: 10.1016/j.gca.2003. 11.021

McKeown, D. A., and Post, J. E. (2001). Characterization of manganese oxide mineralogy in rock varnish and dendrites using X-ray absorption spectroscopy. Am. Miner. 86, 701-713.

Mitchell, D. R. G. (2008). DiffTools: electron diffraction software tools for digital micrograph (TM). Microsc. Res. Tech. 71, 588-593. doi: 10.1002/jemt.20591

Miyata, N., Tani, Y., Iwahori, K., and Soma, M. (2004). Enzymatic formation of manganese oxides by an acremonium-like hyphomycete fungus, strain KR21-2. FEMS Microbiol. Ecol. 47, 101-109. doi: 10.1016/S0168-6496(03)00251-4

Miyata, N., Tani, Y., Maruo, K., Tsuno, H., Sakata, M., and Iwahori, K. (2006a). Manganese(IV) oxide production by Acremonium sp. strain KR21-2 and extracellular $\mathrm{Mn}(\mathrm{II})$ oxidase activity. Appl. Environ. Microbiol. 72, 6467-6473. doi: 10.1128/AEM.00417-06

Miyata, N., Maruo, K., Tani, Y., Tsuno, H., Seyama, H. Soma, M., et al. (2006b). Production of biogenic manganese oxides by anamorphic Ascomycete fungi isolated from streambed pebbles. Geomicrobiol. J. 23, 63-73. doi 10.1080/01490450500533809

Morgan, J. J. (2005). Kinetics of reaction between $\mathrm{O}_{2}$ and $\mathrm{Mn}(\mathrm{II})$ species in aqueous solutions. Geochim.
Cosmochim. Acta 69, 35-48. doi: 10.1016/j.gca.2004.06.013

Newville, M. (2001). IFEFFIT: interactive XAFS analysis and FEFF fitting. $J$. Synchrotron Radiat. 8, 324-332. doi: 10.1107/S0909049500016964

Nico, P. S., Anastasio, C., and Zasoski, R. J. (2002). Rapid photo-oxidation of $\mathrm{Mn}$ (II) mediated by humic substances. Geochim. Cosmochim. Acta 66, 4047-4056. doi: 10.1016/S00167037(02)01001-3

Ogura, Y. (1955). Catalase activity at high concentration of hydrogen peroxide. Arch. Biochem. Biophys. 57, 288-300. doi: 10.1016/00039861(55)90291-5

Richard, L. E., Peake, B. M., Rusak, S. A., Cooper, W. J., and Burritte, D. J. (2007). Production and decomposition of hydrogen peroxide in freshwater. Environ. Chem. 4, 49-54. doi: 10.1071/EN06068

Rose, A. L., and Waite, T. D. (2002) Kinetic model for $\mathrm{Fe}(\mathrm{II})$ oxidation in seawater in the absence and presence of natural organic matter. Environ. Sci. Technol. 36, 433-444. doi: 10.1021/es0109242

Rose, A. L., Webb, E. A., Waite, T. D., and Moffett, J. W. (2008). Measurement and implications of nonphotochemically generated superoxide in the equatorial Pacific Ocean. Environ. Sci. Technol. 42, 2387-2393. doi: 10.1021/es7024609

Rusak, S. A., Peake, B. M., Richard, L. E., Nodder, S. D., and Cooper, W. J. (2011). Distributions of hydrogen peroxide and superoxide in seawater east of New Zealand. Mar. Chem. 127, 155169. doi: 10.1016/j.marchem.2011. 08.005

Santelli, C. M., Pfister, D. H., Lazarus, D., Sun, L., Burgos, W. D., and Hansel, C. M. (2010). Promotion of $\mathrm{Mn}$ (II) oxidation and remediation of coal mine drainage in passive treatment systems by diverse fungal and bacterial communities. Appl. Environ. Microbiol. 76, 4871-4875. doi: 10.1128/AEM. 03029-09

Santelli, C. M., Webb, S. M., Dohnalkova, A. C., and Hansel, C. M. (2011). Diversity of $\mathrm{Mn}$ oxides produced by $\mathrm{Mn}(\mathrm{II})$-oxidizing fungi. Geochim. Cosmochim. Acta 75, 2762-2776. doi: 10.1016/j.gca.2011. 02.022

Saragosti, E., Tchernov, D., Katsir, A., and Shaked, Y. (2010). Extracellular production and degradation of superoxide in the coral Stylophora pistillata and cultured Symbiodinium. PLoS ONE 5:e12508. doi: 10.1371/journal.pone.0012508 
Scully, N. M., Lean, D. R. S., McQueen, D. J., and Cooper, W. J. (1995) Photochemical formation of hydrogen peroxide in lakes: effects of dissolved organic carbon and ultraviolet radiation. Can. J. Fish. Aquat. Sci. 52, 2675-2681. doi: 10.1139/ f95-856

Sunda, W. G., and Huntsman, S. A. (1994). Photoreduction of manganese oxides in seawater. Mar. Chem. 46, 133-152. doi: 10.1016/0304-4203(94)90051-5

Sunda, W. G., and Kieber, D. J. (1994). Oxidation of humic substances by manganese oxides yields low-molecular-weight organic substrates. Nature 367, 62-64. doi: 10.1038/367062a0

Tang, Y., Zeiner, C. A., Santelli, C. M., and Hansel, C. M. (2013). Fungal oxidative dissolution of the $\mathrm{Mn}$ (II)-bearing mineral rhodochrosite and the role of metabolites in manganese oxide formation. Environ. Microbiol. 15, 1063-1077. doi: 10.1111/1462-2920. 12029

Tebo, B. M., Bargar, J. R., Clement, B. G., Dick, G. J., Murray, K. J., Parker, D. L., et al. (2004). Biogenic manganese oxides: properties and mechanisms of formation. Annu. Rev. Earth Planet. Sci. 32, 287-328. doi: 10.1146/annurev.earth.32.101802. 120213
Tebo, B. M., Clement, B. G., and Dick, G. J. (2007). "Biotransformations of manganese," in Manual of Environmental Microbiology, 3rd Edn, eds C. J. Hurst, R. L. Crawford, J. L. Garland, D. A. Lipson, A. L. Mills, and L. D. Stetzenbach (Washington, DC: ASM Press), 1223 1238.

Tebo, B. M., Johnson, H. A., McCarthy, J. K., and Templeton, A. S. (2005). Geomicrobiology of manganese(II) oxidation. Trends Microbiol. 13, 421-428. doi: 10.1016/j.tim.2005. 07.009

Toner, B., Fakra, S., Villalobos, M., Warwick, T., and Sposito, G. (2005). Spatially resolved characterization of biogenic manganese oxide production within a bacterial biofilm. Appl. Environ. Microbiol. 71, 13001310. doi: 10.1128/AEM.71.3.13001310.2005

Trouwborst, R. E., Clement, B. G., Tebo, B. M., Glazer, B. T., and Luther, G. W. III. (2006). Soluble Mn(III) in Suboxic Zones. Science 313, 1955-1957. doi: 10.1126/science. 1132876

van Waasbergen, L. G., Hildebrand, M. and Tebo, B. M. (1996). Identification and characterization of a gene cluster involved in manganese oxidation by spores of the marine Bacillus sp. strain SG-1. J. Bacteriol. 178, 3517-3530.
Vermilyea, A. W., Hansard, S. P., and Voelker, B. M. (2010). Dark production of hydrogen peroxide in the Gulf of Alaska. Limnol. Oceanogr. 55, 580 588. doi: 10.4319/lo.2009.55.2.0580

Villalobos, M., Toner, B., Bargar, J. and Sposito, G. (2003). Characterization of the manganese oxide produced by Pseudomonas putida strain MnB1. Geochim. Cosmochim. Acta 67, 2649-2662. doi: 10.1016/S00167037(03)00217-5

Wang, Y., and Stone, A. T. (2006). The citric acid-MnIII,IVO2 (birnessite) reaction. Electron transfer, complex formation, and autocatalytic feedback. Geochim. Cosmochim. Acta 70, 4463-4476. doi: 10.1016/j.gca.2006.06.1551

Webb, S. M. (2005). SIXpack: a graphical user interface for XAS analysis using IFEFFIT. Phys. Scr. 115, 1011-1014. doi: 10.1238/Physica.Topical.115a01011

Webb, S. M., Tebo, B. M., and Bargar, J. R. (2005a). Structural characterization of biogenic $\mathrm{Mn}$ oxides produced in seawater by the marine Bacillus sp. strain SG-1. Am. Miner. 90, 1342-1357. doi: 10.2138/am.2005. 1669

Webb, S. M., Dick, G. J., Bargar, J. R., and Tebo, B. M. (2005b). Evidence for the presence of $\mathrm{Mn}$ (III) intermediates in the bacterial oxidation of $\mathrm{Mn}(\mathrm{II})$. Proc. Natl. Acad.
Sci. U.S.A. 102, 5558-5563. doi: $10.1073 /$ pnas.0409119102

Conflict of Interest Statement: The authors declare that the research was conducted in the absence of any commercial or financial relationships that could be construed as a potential conflict of interest.

Received: 15 June 2013; paper pending published: 26 July 2013; accepted: 15 August 2013; published online: 03 September 2013.

Citation: Learman DR, Voelker BM, Madden AS and Hansel CM (2013) Constraints on superoxide mediated formation of manganese oxides. Front. Microbiol. 4:262. doi: 10.3389/fmicb. 2013.00262

This article was submitted to Microbiological Chemistry, a section of the journal Frontiers in Microbiology.

Copyright (c) 2013 Learman, Voelker, Madden and Hansel. This is an openaccess article distributed under the terms of the Creative Commons Attribution License (CC BY). The use, distribution or reproduction in other forums is permitted, provided the original author(s) or licensor are credited and that the original publication in this journal is cited, in accordance with accepted academic practice. No use, distribution or reproduction is permitted which does not comply with these terms. 